\title{
Electrocatalytic Activity and Electrochemical Impedance Spectroscopy of Poly(Aniline-Co-Ortho-Phenylenediamine) Modified Electrode on Ascorbic Acid
}

\author{
ALI PARSA* and SARA AMANZADEH-SALOUT \\ Department of Chemistry, College of Science, Yadegar -e- Imam Khomeini (RAH), \\ Shahre-rey Branch, Islamic Azad University, Tehran, Iran. \\ ${ }^{*}$ Corresponding author E-mail: aliparsa@iausr.ac.ir \\ http://dx.doi.org/10.13005/ojc/320432
}

(Received: June 06, 2016; Accepted: July 21, 2016)

\begin{abstract}
The poly(aniline-co-ortho-phenylenediamine) modified composite graphite (poly(Anico-OPDA)/CG)) has shown excellent electrocatalytic response towards the oxidation of ascorbic acid (AA). The anodic peak potential $\left(E_{\mathrm{pa}}\right)$ of $A A$ has shifted from $+0.48 \mathrm{~V}$ (bare $\mathrm{CG}$ ) to $+0.17 \mathrm{~V}$ (poly(Ani-Co-oPDA/CG)). The anodic peak currents $\left(\mathrm{I}_{\mathrm{p}}\right)$ are linearly dependent upon the square root of scan rate indicating a favourable diffusion controlled process. The electro oxidation of AA on poly(Ani-Co-oPDA/CG is more feasible in acidic medium than in either neutral or alkaline medium. This is shown by negative shift of $E_{p a}$. The charge transfer resistance $\left(R_{c t}\right)$ at the poly(Ani-co-oPDA/ $C G)$ shows that the rate of the electro oxidation of $A A$ changes with electrode potential. The $R_{c t}$ and diffusion process are dependant not only on applied potential and electrode material but also on the AA.
\end{abstract}
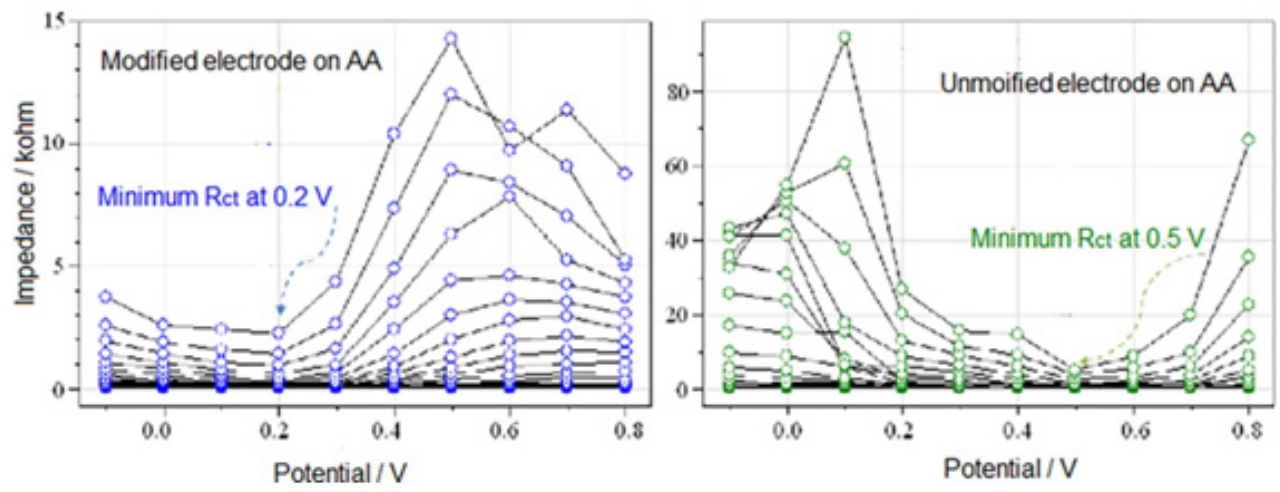

The poly(aniline-co-ortho-phenylenediamine) modified composite graphite (CG) electrode has shown excellent electrocatalytic response towards the oxidation of ascorbic acid (AA). Charge transfer resistance $\left(\mathrm{R}_{\mathrm{ct}}\right)$ at the poly(Ani-Co-oPDA/CG) shows that the rate of the electro oxidation of AA changes with electrode potential. 
Keywords: Ascorbic acid; Electrochemical impedance spectroscopy; Electrocatalytic oxidation; Ortho-Phenylenediamine.

\section{INTRODUCTION}

The determination of ascorbic acid (AA) has become very important since $A A$ is known to be present in human brain and also involves in several biological processes ${ }^{1}$. Recent studies have demonstrated that the AA content in biological fluids is useful in assessing the amount of oxidative stress in human metabolism². The excessive oxidative stress has been linked to cancer, diabetes mellitus and hepatic disease.

Voltametric studies of $A A$ on bare electrode have not been very successful| ${ }^{3-6}$. The main cause is the high over potential of AA besides the fouling effect of the oxidation products, poor reproducibility, low selectivity and poor sensitivity. However, this is overcome by modifying the electrode with mediators $^{7-9}$ and polymers ${ }^{10-12}$.

The electrochemical copolymerization of aniline (Ani) with its derivatives has been reported $^{13-19}$ These have significantly improved the electrochemical activity of polyaniline (PAni). The electro copolymerization of Ani with other monomers is, however, not feasible and even in some cases impossible. The reason is large peak potentials separation ("Ep) between them which hindered the formation of the copolymer. Hence, the smaller the "Ep the better it is for the copolymerization to occur ${ }^{20-24}$.

The electrochemical impedance spectroscopy (EIS) is a useful technique to investigate the interfacial properties of modified electrodes ${ }^{25-30}$. The EIS is, usually, utilized to study parameters such as charge transfer resistance $\left(R_{c t}\right)$, double layer capacitance $\left(C_{d l}\right)$, faradaic capacitance etc. of modified electrodes ${ }^{31-34}$. EIS on PAni and its derivatives modified electrodes have been reported ${ }^{34-37}$

This work reports on the electrochemical behaviour and catalytic ability of poly(Ani-Co-oPDA) modified CG electrode towards electro-oxidation of AA.

\section{MATERIALS AND METHODS}

Aniline (Sigma Chemicals, USA) was purified by distillation under a nitrogen atmosphere at reduced pressure. The resulting colorless liquid was kept in the dark at $5^{\circ} \mathrm{C}$. The ortho-phenylenediamine (oPDA) and phosphoric acid (Sigma Chemicals, USA) were used as received. Ascorbic acid (AA) (Fluka Chemical, Switzerland) solution was prepared fresh in $0.1 \mathrm{~mol} \mathrm{~L}^{-1}$ phosphate buffer solution, $\mathrm{pH}$ 6.8. All aqueous solutions were prepared using ultra pure water from Milli $Q$ plus system (Millipore Corp., USA). Oxygen-free nitrogen (OFN) was obtained from Nissan-IOI, Malaysia.

\section{Equipment}

CV was carried out using an electrochemical Autolab PGSTAT system (Eco. Chemie B.V., Netherlands). The system was run on a PC using general-purpose electrochemical system (GPES 4.9) software. A three-compartment electrochemical cell was employed during synthesis and characterization of copolymer. The 2B pencil composite graphite (CG) Lumograph (Staedtler, Germany) was used as working and counter electrodes against pseudo $\mathrm{Ag} / \mathrm{AgCl}$ reference electrode.EIS measurements were taken using the CompactStatpotentiostat (CompactStat; Ivium Technologies, Netherlands) controlled by a computer equipped with the IviumSoft software package. The structure of copolymer was determined by FTIR spectroscopy System 2000 (Perkin Elmer, USA).

\section{Procedure}

The electro copolymerization was performed using $25 \mathrm{~mL}$ solution of the $50 \mathrm{~m} \mathrm{~mol} \mathrm{~L}^{-1}$ Ani and oPDA, $1 \mathrm{~mol} \mathrm{~L}^{-1} \mathrm{H}_{3} \mathrm{PO}_{4}$ and $0.06 \mathrm{~mol} \mathrm{~L}^{-1} \mathrm{Ca}_{3}\left(\mathrm{PO}_{4}\right)_{2}$ by sweeping the potential between " $0.7 \mathrm{~V}$ and $+0.8 \mathrm{~V}$ (vs. $\mathrm{Ag} / \mathrm{AgCl}$ ), at a scan rate $100 \mathrm{mV} \mathrm{s"1}$, under OFN atmosphere and at $25 \pm 2 \stackrel{\circ}{ } \mathrm{C}$.

The electrochemical determination of $A A$ was performed using $25 \mathrm{~mL}$ solution containing $2 \mathrm{~m} \mathrm{~mol} \mathrm{~L}-1$ AA and $1 \mathrm{~mol} \mathrm{~L}^{-1} \mathrm{H}_{3} \mathrm{PO}_{4}$ by sweeping the potential between " $0.45 \mathrm{~V}$ to $+0.65 \mathrm{~V}$ at a scan rate $100 \mathrm{mVs}^{\prime 1}$, under OFN atmosphere and at $25 \pm 2^{\circ} \mathrm{C}$. 
Copolymer film was repeatedly washed with supporting electrolyte and then placed in monomer free supporting electrolyte containing AA at different applied dc potentials to perform ac impedance measurements. The potential amplitude of ac impedance was kept at $10 \mathrm{mV}$ with its frequency range from $100 \mathrm{kHz}$ to $10 \mathrm{mHz}$.

\section{RESULTS AND DISCUSSION}

\section{Electrosynthesis of copolymer Ani and oPDA}

The CVs of copolymerization of Ani and oPDA in $1 \mathrm{~mol} \mathrm{~L}^{-1} \mathrm{H}_{3} \mathrm{PO}_{4}$ containing $0.06 \mathrm{~mol} \mathrm{~L}^{-1}$ $\mathrm{Ca}_{3}\left(\mathrm{PO}_{4}\right)_{2}$ is shown in Figure 1a. The details have been reported elsewhere ${ }^{38}$. Figure $1 \mathrm{~b}$ shows FT-IR spectra bands at $1634-1618 \mathrm{~cm}^{-1}$ indicating the existence of oPDA in the copolymer ${ }^{39}$. The
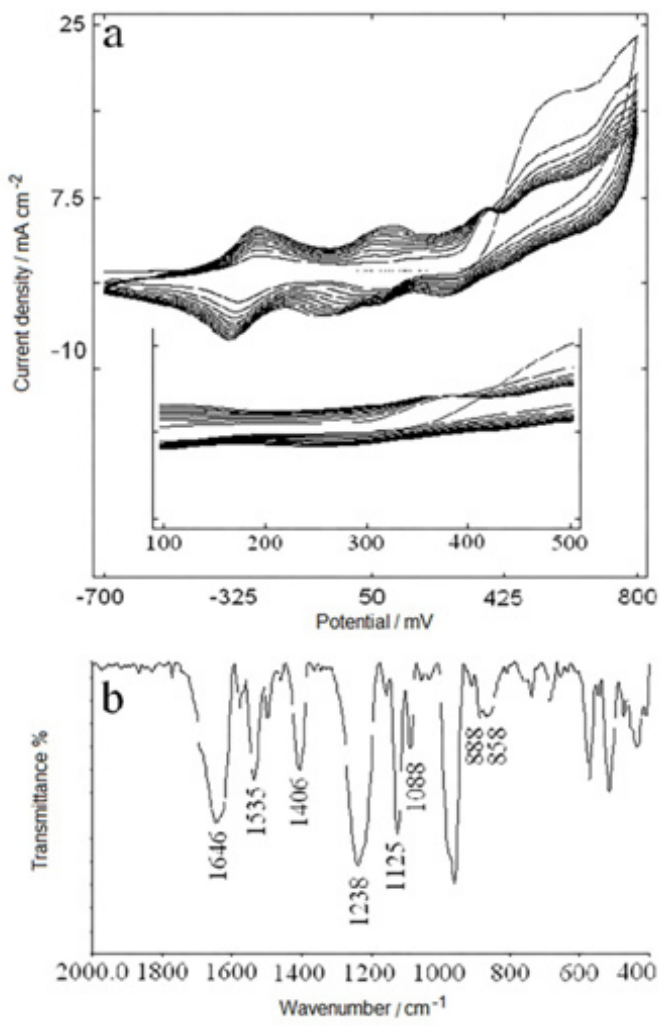

Fig. 1: (a) The CVs of $50 \mathrm{mmol} \mathrm{L}^{-1} \mathrm{Ani}$ and 50 mmol L-1 oPDA in 1 mol L-1 $\mathrm{H}_{3} \mathrm{PO}_{4}$ containing $0.06 \mathrm{~mol} \mathrm{~L}^{-1} \mathrm{Ca}_{3}\left(\mathrm{PO}_{4}\right)_{2}$. The applied potential, $\mathrm{E}_{\mathrm{app}}$, "0.7 and $+0.8 \mathrm{~V}$ (vs. $\mathrm{Ag} / \mathrm{AgCl}$ ), scan rate of $100 \mathrm{mVs}$ " 1 and scanning up to 10 cycles.

(b) Baseline corrected FTIR spectrum of copolymer appearance of bands at 1068-1064, 884 and 850 $\mathrm{cm}^{-1}$ suggests the presence of phenazine-like cyclic structures in the copolymer backbone ${ }^{40}$. These could either be due to the presence of PoPDA blocks or of

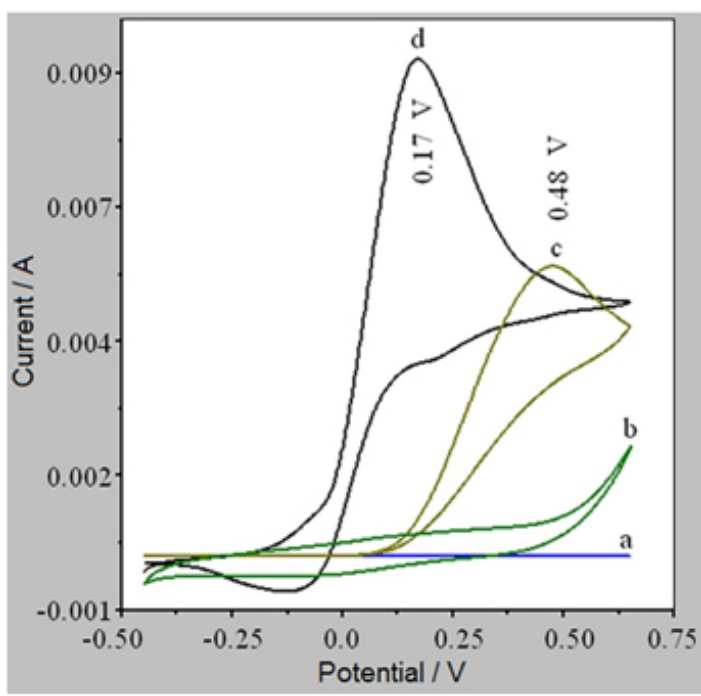

Fig. 2: CVs of (a) bare CG and (b) poly(Ani-cooPDA)/CG electrodes in $1 \mathrm{~mol} \mathrm{~L}^{-1} \mathrm{H}_{3} \mathrm{PO}_{4}(\mathrm{pH}=1)$ without AA present. CVs of (c) bare $C G$ and (d) poly(Ani-co-oPDA)/CG electrodes in $1 \mathrm{~mol} \mathrm{~L}^{-1}$ $\mathrm{H}_{3} \mathrm{PO}_{4}(\mathrm{pH} \mathrm{1})$ in the presence of $2 \mathrm{mmol} \mathrm{L}^{-1} \mathrm{AA}$

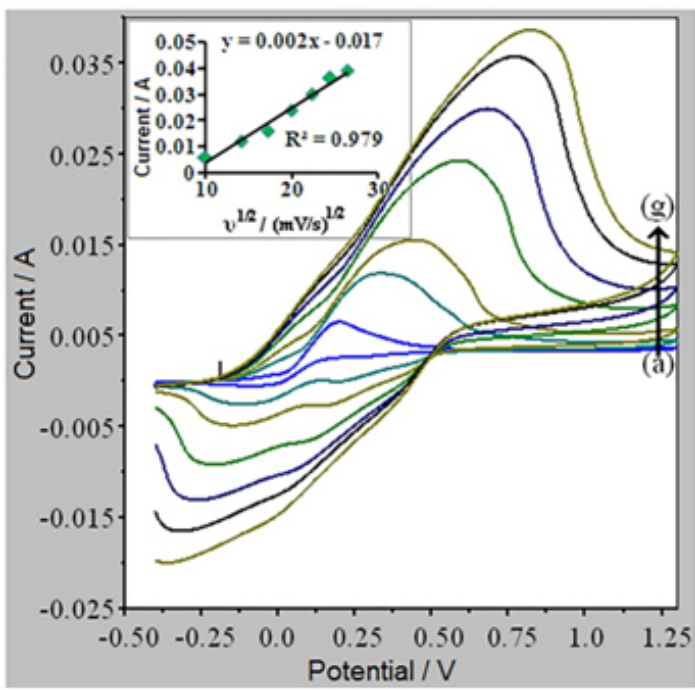

Fig. 3: CVs of $1 \mathrm{mmol} \mathrm{L}^{-1} \mathrm{AA}$ at poly(Ani-cooPDA)/CG in $1 \mathrm{~mol} \mathrm{~L}^{-1} \mathrm{H}_{3} \mathrm{PO}_{4}(\mathrm{pH}=1)$ at scan rates (o) from (a) to (g) at 100, 200, 300, 400, 500,600 and $700 \mathrm{mV} \mathrm{s}$ "1, respectively. Inset shows the plot of $I_{p a} v s$. $v^{1 / 2}$ 
the adjacent oPDA and Ani unit in the copolymeric chain ${ }^{38}$.

\section{Electrocatalytic oxidation of AA}

Figure 2c shows that the anodic peak potential $\left(E_{p a}\right)$ of $A A$ appears at $+0.48 \mathrm{~V}$ on bare $\mathrm{CG}$ with the anodic peak current $\left(\mathrm{I}_{\mathrm{pa}}\right)$ at $5 \mathrm{~mA}$. It is an irreversible electrode process. In contrast, on poly(Ani-co-oPDA)/CG the $\mathrm{I}_{\mathrm{pa}}$ has increased to $9 \mathrm{~mA}$ and the $\mathrm{E}_{\mathrm{pa}}$ has shifted negatively to $+0.17 \mathrm{~V}$ (Fig. 2d) with quasi reversible electrode process. This shows that the electro oxidation of $A A$ is feasible indicating a strong electrocatalytic property of poly(Ani-cooPDA)/CG towards AA. The shifting of the $E_{p a}$ is due to the kinetic effect in which a substantial increase in the rate of electron transfer is observed ${ }^{41}$.

Rueda et $\mathrm{A}^{\mathrm{A2}}$ have studied the oxidation of $\mathrm{AA}$ on a gold electrode in a wide $\mathrm{pH}$ range. The products of the reaction have been identified by chromatography. From electrochemical experiments, the total number of electrons taking part in the oxidation has been estimated at 1.9. On this basis the following $E C$ mechanism have been proposed:

$$
\begin{aligned}
& \mathrm{H}_{2} \mathrm{~A} \rightarrow \mathrm{A}+2 \mathrm{H}^{+}+2 \mathrm{e}^{-} \\
& \mathrm{A}+\mathrm{H}_{2} \mathrm{O} \rightarrow \mathrm{B}
\end{aligned}
$$

Where $\mathrm{H}_{2} \mathrm{~A}$ is $\mathrm{AA}$, A stands for the dehydro ascorbic acid (DHAA) and $B$ is hydrated dehydro ascorbic acid (DHAA. $\mathrm{H}_{2} \mathrm{O}$ ). The DHAA is formed from $\mathrm{H}_{2}$ Avia a radical anion intermediate viz. mono

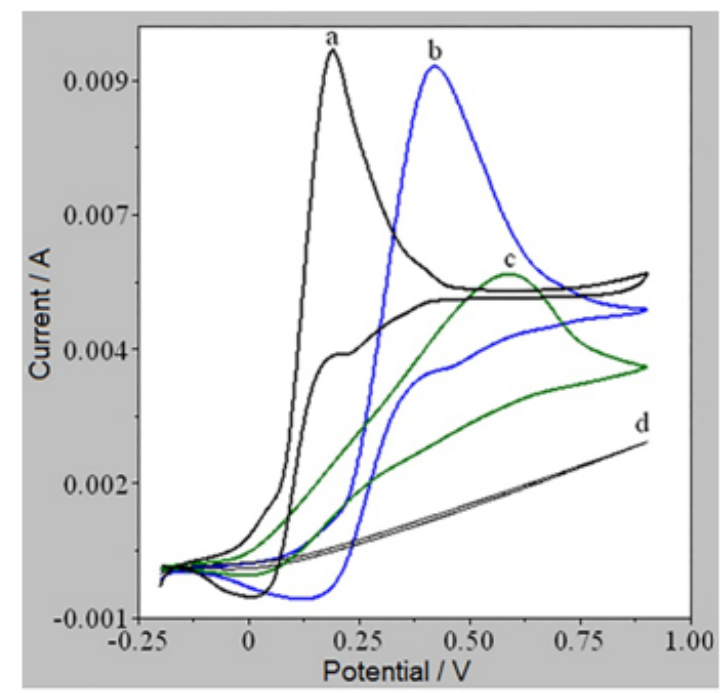

Fig. 4: CVs of $2 \mathrm{mmol} \mathrm{L}^{-1} \mathrm{AA}$ at poly(Ani-cooPDA)/CG electrode at (a) $\mathrm{pH}=1$, (b) $\mathrm{pH}=4$, (c) $\mathrm{pH}=8$ and (d) $\mathrm{pH}=12$. Scan rate is $100 \mathrm{mVs}^{-1}$ dehydro ascorbic acid. The DHAA undergoes a hydration reaction to form the final product, the electro inactive DHAA. $\mathrm{H}_{2} \mathrm{O}$. The irreversibility of the electro oxidation of $\mathrm{AA}$ is displayed by the absence of the cathodic peak current $\left(I_{p c}\right)$ (Figure 2).

\section{Effect of scan rate}

Further investigation is carried out on the transport characteristics of AA on the modified electrodes. It is apparent that with increasing scan

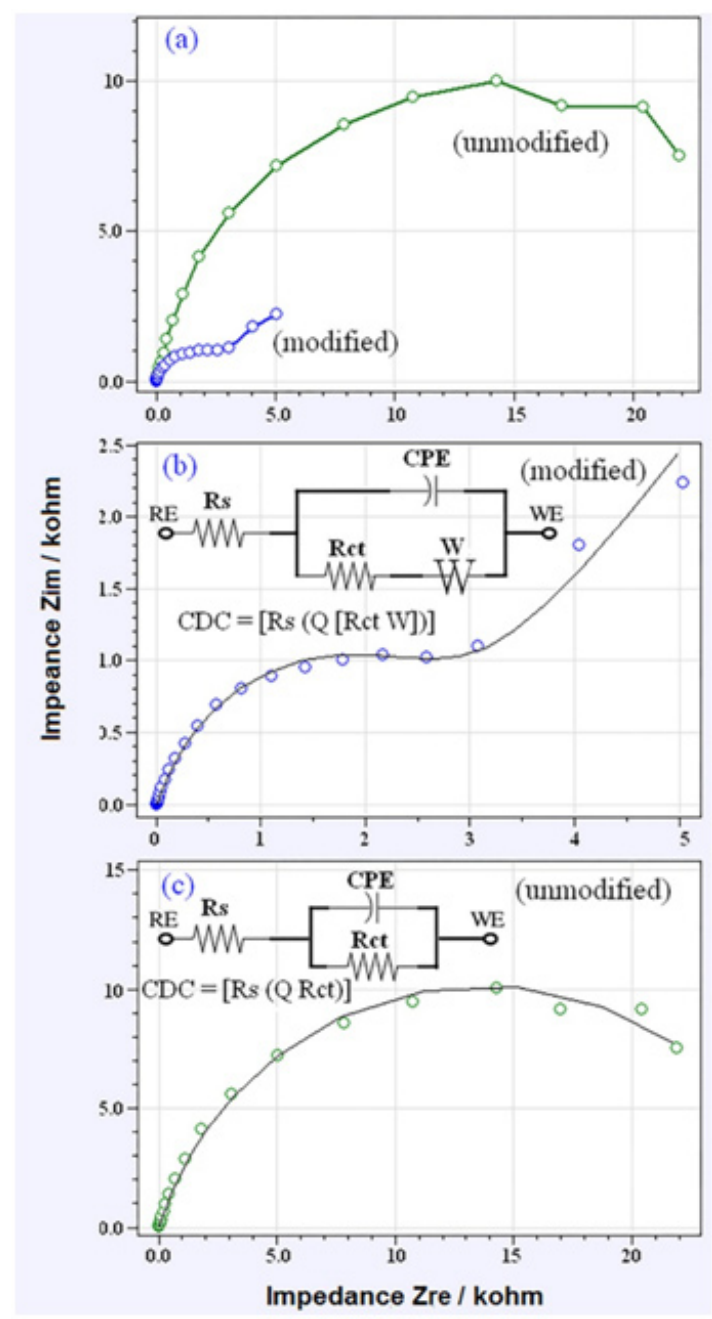

Fig. 5: (a) Nyquist plots of AA at the poly(Anico-oPDA)/CG and bare CG electrodes at $E_{\text {app }} 0.20 \mathrm{~V}$. (b) and (c) are the respective electrodes with Randle's equivalent circuit and circuit description code (CDC) (inset). The ac potential amplitude was kept at $10 \mathrm{mV}$ and frequency range used was from $100 \mathrm{kHz}$ to $10 \mathrm{mHz}$ 
rates the $E_{p a}$ is shifted to more positive potentials indicating there is kinetic limitation on the electrode process (Figure 3). But, as $\mathrm{I}_{\mathrm{pa}}$ is directly proportional to the square root of scan rates the electrode process is, predominantly, diffusion-controlled ${ }^{43}$. This is regarded as normal for a useful electrode process.

\section{Effect of $\mathrm{pH}$}

The CVs of $2 \mathrm{~m} \mathrm{~mol} \mathrm{~L}^{-1} \mathrm{AA}$ in supporting electrolytes at different $\mathrm{pH}$ values at poly(Ani-co-
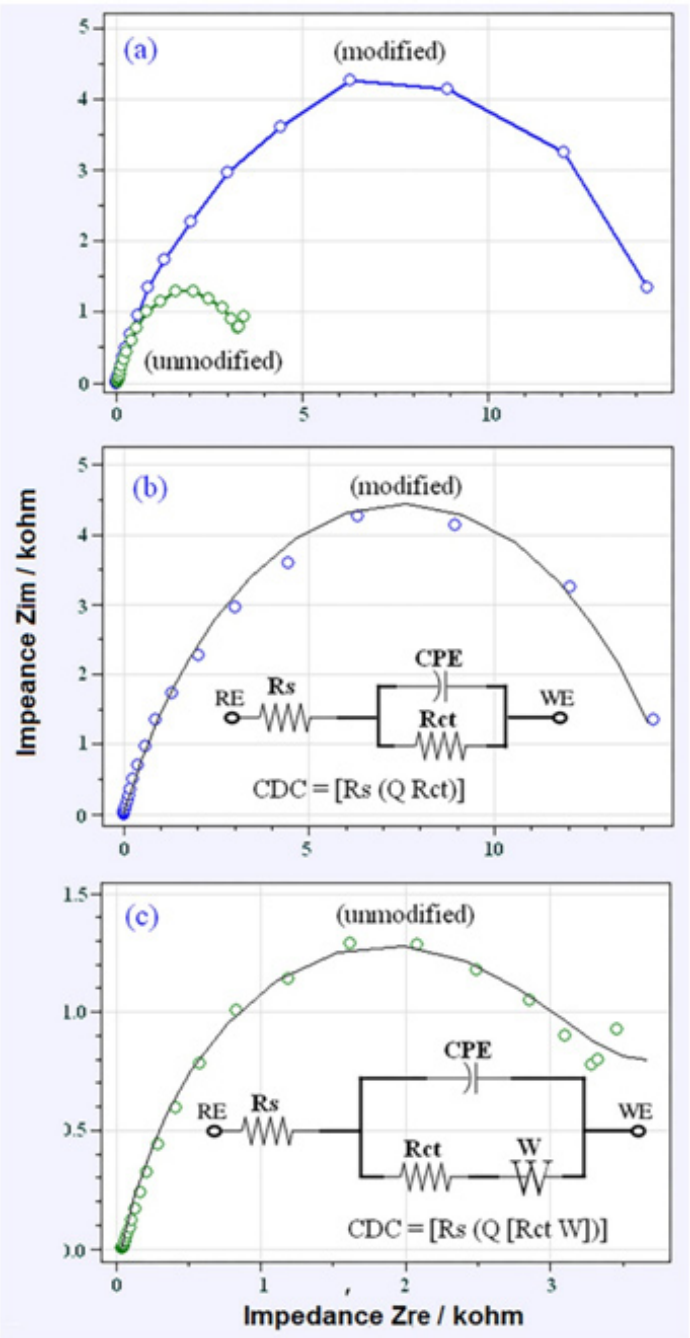

Fig. 6: (a) Nyquist plots of AA at the poly(Anico-oPDA)/CG and bare CG electrodesat $E_{\text {app }} 0.50$ V. (b) and (c) are the respective electrodes with Randle's equivalent circuit and circuit description code (CDC) (inset). The ac potential amplitude was kept at $10 \mathrm{mV}$ and frequency range used was from $100 \mathrm{kHz}$ to $10 \mathrm{mHz}$
oPDA)/CG are shown in Figure 4. It appears that there is a decrease in $\mathrm{I}_{\mathrm{pa}}$ when $\mathrm{pH}$ is raised from 1 to 12 . The decrease in the electrode process is due to higher electronic conductivity of poly(Anico-oPDA) in acid than in basic media ${ }^{44,45}$. With an increase in $\mathrm{pH}$ the $\mathrm{E}_{\mathrm{pa}}$ is shifted towards positive indicating the decrease in electro catalysis of poly(Ani-co-oPDA)/CG. Hence, the electro oxidation of $A A$ on the poly(Ani-co-oPDA)/CG is more feasible in acid than in either neutral or alkaline media.
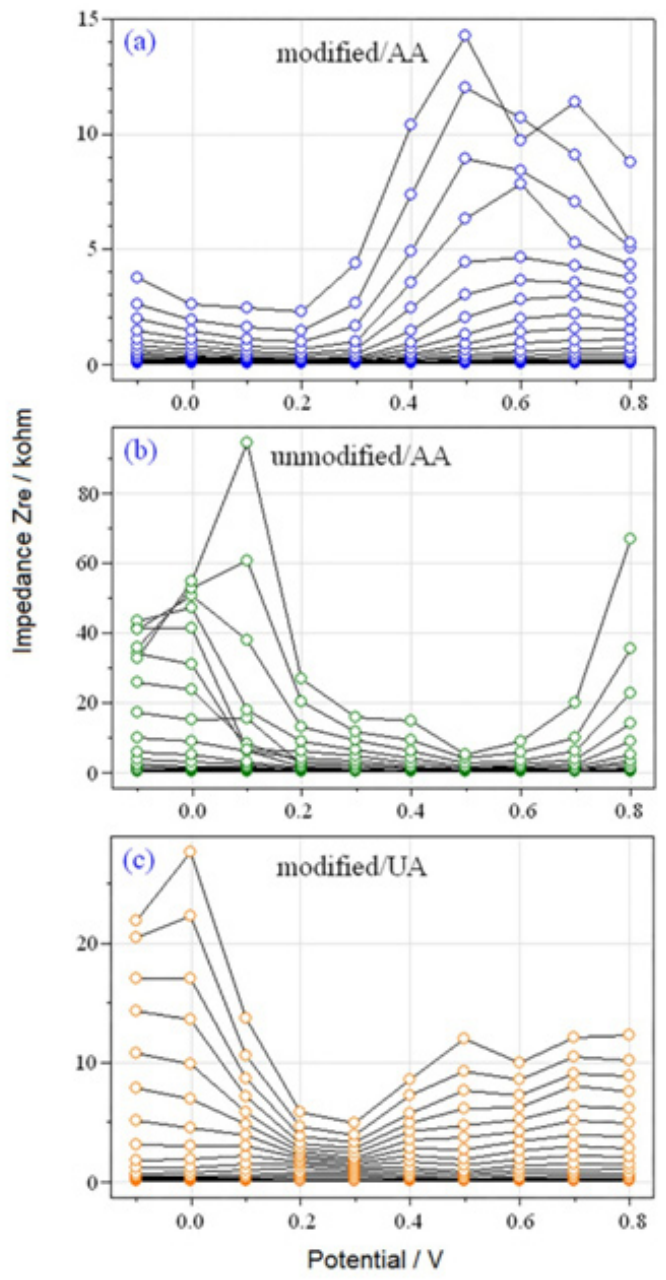

Fig. 7: Real impedance spectroscopy $\left(Z_{\mathrm{re}}\right)$ of poly(Ani-co-oPDA)/CG in monomer free background electrolyte containing (a) AA and (c) UA obtained by sweeping the potential between "0.1 and 0.8 V (vs. Ag/AgCl). (b) Real impedance spectroscopy $\left(Z_{r e}\right)$ of bare $C G$ electrode in the same environment as the above 
Therefore, the poly(Ani-co-oPDA)/CG is useful for electro oxidation of $\mathrm{AA}$ in acidic $\mathrm{pH}$ range.

\section{EIS studies}

It is well known that EIS is a useful method for studying the interfacial properties of the modified electrodes ${ }^{46}$. The impedance is the summation of real, $Z_{\mathrm{re}}$, and imaginary, $\mathrm{Z}_{\mathrm{im}}$, components contributed by the resistance and capacitance of the cell ${ }^{47}$. In this study EIS was employed to investigate electro oxidation of $\mathrm{AA}$ at poly(Ani-co-oPDA)/CG and bare $C G$ electrodes. EIS measurements of $A A$ in a monomer-free supporting electrolyte solution were performed at two different potentials.

From Figure $5 \mathrm{a}$ it is obvious that the magnitude of charge transfer resistance $\left(R_{c t}\right)$, the diameter of the semi circle, of poly(Ani-co-oPDA)/ CG is smaller $\left(2.900 \times 10^{3} \mathrm{ohm}\right)$ than bare CG $\left(2.750 \times 10^{4} \mathrm{ohm}\right)$ indicating improved interfacial capacitance. In short, double-layer capacitance $\left(C_{d l}\right)$ of constant phase element (CPE or $Q$ ) has encouraged charge transfer. The presence of straight line on $\mathrm{poly}(\mathrm{Ani}$-co-oPDA)/CG with a slope of $45^{\circ} \mathrm{C}$ at the lower frequency indicates a favourable diffusion-controlled mass transport process ${ }^{48}$.

The total impedance is measured by several parameters: the bulk electrolyte solution resistance $\left(R_{s}\right)$, charge transfer resistance $\left(R_{c t}\right)$ that corresponds to the kinetic control of the chargetransfer process, double layer capacitance $\left(\mathrm{C}_{\mathrm{dl}}\right)$ and Warburg impedance $\left(Z_{w}\right)$. To take a proper fitting of the Nyquist plots, it was needed to replace $C_{d l}$ with a CPE in the Randles' equivalent circuit. It's widely believed explanation for the appearance of depressed semi circles and the presence of CPE in the Nyquist plots is due to microscopic roughness, which causes an inhomogeneous distribution in both $\mathrm{C}_{\mathrm{dl}}$ and $\mathrm{R}_{\mathrm{s}}{ }^{49-51}$. The circuit element that is of most interest to this work is $R_{c t}$. This is because it often relates directly to the accessibility of the modified electrode and also reflects the flow of charge across the modified interface into the substrate electrode.

The decrease in diameter of the semicircle confirms the electrocatalytic activity of poly(Ani-CooPDA)/CG in the oxidation of $A A$ at $E_{\text {app }} 0.2 \mathrm{~V}$. The electro oxidation of $A A$ that occurred via phenazinelike cyclic species virtually led to an increase in the surface concentration of low-valence species of the electrocatalyst and the decline of the $R_{c t}$ depending on the concentration of AA in the solution as shown in Figure $5 c, R_{c t}$ is high enough at $0.2 \mathrm{~V}$, where the mass transfer process is not performed, so in the Nyquist plots no $Z_{w}$ is observed.

At $E_{\text {app }} 0.5 \mathrm{~V}$ the result shows the inverse as magnitude of $R_{c t}$ of poly(Ani-co-oPDA)/CG (15000 ohm) is much higher than the bare CG (3400 ohm) and with $Z_{w}$ is not observed (Figure $6 b)$. This suggests on the dependancy of diffusion process of $A A$ on the $E_{\text {app }}$. Values of the Randles equivalent circuit elements obtained by fitting the experimental results for the Nyquist plots in monomer free background electrolyte containing $A A$ at the poly(Ani-co-oPDA)/CG and bare CG at $\mathrm{E}_{\text {app }}$ of 0.2 and $0.50 \mathrm{~V}$ are listed in Table 1.

Table 1: The best fitting values of the Randles' equivalent circuit elements in Figures 5 and 6 from the simulation of the impedance data for poly(Ani-co-oPDA)/ CG and CG electrodes

\begin{tabular}{|c|c|c|c|c|}
\hline \multirow{2}{*}{$\begin{array}{l}E_{\text {app }}(V) \\
\text { Electrode }\end{array}$} & \multicolumn{2}{|c|}{0.2} & \multicolumn{2}{|c|}{0.5} \\
\hline & Modified & Unmodified & Modified & Unmodified \\
\hline $\mathrm{R}_{\mathrm{s}}(\mathrm{ohm})$ & 10 & $2.620 \times 10^{1}$ & 7.20 & $4.000 \times 10^{1}$ \\
\hline $\mathrm{R}_{\mathrm{ct}}(\mathrm{ohm})$ & $2.900 \times 10^{3}$ & $2.750 \times 10^{4}$ & $1.500 \times 10^{4}$ & $3.400 \times 10^{3}$ \\
\hline W 1/(Ohm sqrt(Hz) & $5.950 \times 10^{2}$ & & & $1.200 \times 10^{2}$ \\
\hline $\mathrm{CPE}(\mathrm{F})$ & $1.650 \times 10^{-6}$ & $1.810 \times 10^{-5}$ & & $3.000 \times 10^{-5}$ \\
\hline$\alpha$ & $7.200 \times 10^{-1}$ & $8.105 \times 10^{-1}$ & $4.500 \times 10^{-7}$ & $7.950 \times 10^{-1}$ \\
\hline & & & $6.805 \times 10^{-1}$ & \\
\hline
\end{tabular}

$\alpha$ : Degree of electrode surface roughness or Cell geometry. 
Further investigation shows that the poly(Ani-Co-OPDA)/CG electrode has minimum $Z_{\text {re }}$ at $E_{\text {app }} 0.2 \mathrm{~V}$, whereas the $C G$ electrode shows minimum $Z_{\text {re }}$ at $E_{\text {app }} 0.5 \mathrm{~V}$ at frequency $100 \mathrm{kHz}$ to $10 \mathrm{mHz}$ (Figures 7a and 7b). Figure 7c shows real impedance spectroscopy $\left(Z_{\mathrm{re}}\right.$ or $\left.Z \times\right)$ of poly(Ani-COoPDA)/CG electrode in monomer free background electrolyte containing uric acid (UA) obtained by sweeping the potential between " 0.1 and $0.8 \mathrm{~V}$ (vs. $\mathrm{Ag} / \mathrm{AgCl}$ ). The poly(Ani-Co-oPDA)/CG electrode has its minimum $Z_{r e}$ at $E_{\text {app }} 0.3 \mathrm{~V}$. Thus, the $R_{c t}$ and diffusion process depend not only on $E_{\text {app }}$ and electrode material but also on type of analyte available.

\section{CONCLUSION}

The poly(Ani-co-oPDA)/CG electrode is shown to possess catalytic activity towards the oxidation reaction of $\mathrm{AA}$. As a result, the electro oxidation of $A A$ on the modified electrode is more feasible in acidic than in neutral and alkaline medium. This is shown by negative shift of $E_{p a}$ of $A A$. The extension of catalytic reaction depends on charge transfer. The electrode process is diffusion-controlled.
The study indicates the poly(Ani-co-oPDA)/CG electrode is useful for oxidation of $A A$ in an acidic range of $\mathrm{pH}$.

The electrochemical impedance spectroscopy was successfully used to interpret the electrocatalytic effect of modified electrode on AA. The equivalent circuit elements obtained by fitting the experimental results confirmed that proposed equivalent circuits were matched and able to explain phenomenon in the modified and unmodified electrode. The $\mathrm{R}_{\mathrm{ct}}$ and diffusion process are not only dependent on applied potential and electrode material but also on type of analyte used. The $R_{c t}$ is the only circuit element that is meaningful. It describes on the kinetic of charge transfer during the electro oxidation of AA at different applied potential.

\section{ACKNOWLEDGMENT}

This work is supported by Yadegar -e- Imam Khomeini (RAH) Shahre-rey Branch, Islamic Azad University, Tehran, Iran for Research University (RU) grant - 1395/1742:90/07/27.

\section{REFERENCES}

1. Männistö, P.T.; Kaakkola, S. Pharmacol. Rev. 1999, 51, 593-628.

2. Koshiishi, I.; Imanari, T. Anal. Chem. 1997, 69, 216-220 .

3. Kalakodimi, R. P.; Nookala, M. Anal. Chem. 2002, 74, 5531-5537.

4. Khoo, S. B.; Chen, F. Anal. Chem. 2002, 74, 5734-5741.

5. Lertanantawong, B.; O’Mullane, A. P.; Zhang, J.; Surareungchai, W.; Somasundrum, M.; Bond, A. M. Anal. Chem. 2008, 80, 6515-6525

6. Malinauskas, A.; Garjonyt, R.; Mapeikien, R.; Jurevièiût, I. Talanta. 2004, 64, 121-129 .

7. Balamurugan, J.; Senthil Kumar, S. M.; Thangamuthu, R.; Pandurangan, A. J. Mol. Catal. A: Chem. 2013, 372, 13-22 .

8. Wei, M.-Y.; Huang, R.; Guo, L.-H. J. Electroanal.
Chem. 2012, 664, 156-160 .

9. Wu, M.; Mao, X.; Li, X.; Yang, X.; Zhu, L. J. Electroanal. Chem. 2012, 682, 1-6.

10. Abdelwahab, A. A.; Kim, D.-M.; Halappa, N. M.; Shim, Y.-B. Electroanalysis. 2013, 25, 1178-1184.

11. Chih, Y.-K.; Yang, M.-C. Bioelectrochemistry. 2013, 91, 44-51.

12. Kalimuthu, P.; John, S. A. Bioelectrochemistry. 2009, 77, 13-18.

13. Mu, S. Synth. Met. 2004, 143, 259-268 .

14. Sato, M.; Yamanaka, S.; Nakaya, J.-i.; Hyodo, K. Electrochim. Acta. 1994, 39, 2159-2167.

15. Shah, A.-u.-H. A.; Holze, R. J. Solid State Electrochem. 2007, 11, 38-51.

16. Si, S.; Xu, Y.; Nie, L.; Yao, S. Electrochim. Acta. 1995, 40, 2715-2721.

17. Tang, H.; Kitani, A.; Maitani, S.; Munemura, 
H.; Shiotani, M. Electrochim. Acta. 1995, 40, 849-857.

18. Wei, Y.; Hariharan, R.; Patel, S. A. Macromolecules. 1990, 23, 758-764 .

19. Yang, C. H.; Wen, T. C. J. Appl. Electrochem. 1994, 24, 166-178.

20. Su, N. Nanoscale Res. Lett. 2015, 10, 1-9.

21. Ojani, R.; Hamidi, P.; Raoof, J.-B. Chin. Chem. Lett. 2016, 27, 481-486.

22. Rezaei, B.; Boroujeni, M. K.; Ensafi, A. A. Sensors Actuators B: Chem. 2016, 222, 849856 .

23. Morteza, E.; Roya, D. Oriental Journal of Chemistry. 2015, 31, 1185-1189.

24. Udmale, V.; Mishr, D.; Gadhave, R.; Pinjare, D.; Yamgar, R. Oriental Journal of Chemistry. 2013, 29, 927-936 .

25. Arslan, A.; Hur, E. Chemical Papers. 2014, 68, 504-515.

26. Atta, N. F.; El-Kady, M. F.; Galal, A. Anal. Biochem. 2010, 400, 78-88 .

27. Atta, N. F.; Galal, A.; Khalifa, F. Appl. Surf. Sci. 2007, 253, 4273-4282 .

28. Branzoi, V.; Branzoi, F.; Pilan, L. Mater. Chem. Phys. 2009, 118, 197-202.

29. Manjunatha, R.; Suresh, G. S.; Melo, J. S.; D'Souza, S. F.; Venkatesha, T. V. Sensors Actuators B: Chem. 2010, 145, 643-650

30. Wang, X.; Bernard, M. C.; Deslouis, C.; Joiret, S.; Rousseau, P. Electrochim. Acta. 2011, 56, 3485-3493 .

31. Kim, Y.-R.; Bong, S.; Kang, Y.-J.; Yang, Y.; Mahajan, R. K.; Kim, J. S.; Kim, H. Biosens. Bioelectron. 2010, 25, 2366-2369.

32. Liu, X.-X.; Dou, Y.-Q.; Wu, J.; Peng, X.-Y. Electrochim. Acta. 2008, 53, 4693-4698.

33. Gobal, F.; Faraji, M. Electrochim. Acta. 2013, 100, 133-139.

34. Córdoba-Torres, P.; Mesquita, T. J.; Devos, O.; Tribollet, B.; Roche, V.; Nogueira, R. P.
Electrochim. Acta. 2012, 72, 172-178 .

35. Hallik, A.; Alumaa, A.; Tamm, J.; Sammelselg, V.; Väärtnõu, M.; Jänes, A.; Lust, E. Synth. Met. 2006, 156, 488-494 .

36. Lissy, S. L. G.; Pitchumani, S.; Jayakumar, K. Mater. Chem. Phys. 2002, 76, 143-150 .

37. Ameen, S.; Shaheerakhtar, M. Oriental Journal of Chemistry. 2013, 29, 837-860 .

38. Parsa, A.; Ab Ghani, S. Polymer. 2008, 49, 3702-3708 .

39. Huang, M. R.; Li, X. G.; Duan, W. Polym. Int. 2005, 54, 70-82.

40. Murugesan, R.; Subramanian, E. Mater. Chem. Phys. 2003, 80, 731-739 .

41. Zhang, L.; Lian, J. J. Electroanal. Chem. 2007, 611, 51-59 .

42. Rueda, M.; Aldaz, A.; Sanchez-Burgos, F. Electrochim. Acta. 1978, 23, 419-424 .

43. Hu, Z.-A.; Shang, X.-L.; Yang, Y.-Y.; Kong, C.; Wu, H.-Y. Electrochim. Acta. 2006, 51, 33513355 .

44. Nekrasov, A. A.; Ivanov, V. F.; Vannikov, A. V. Electrochim. Acta. 2001, 46, 4051-4056.

45. Ostwal, M. M.; Qi, B.; Pellegrino, J.; Fadeev, A. G.; Norris, I. D.; Tsotsis, T. T.; Sahimi, M.; Mattes, B. R. Ind. Eng. Chem. Res. 2006, 45, 6021-6031.

46. Feng, L.-J.; Zhang, X.-H.; Zhao, D.-M.; Wang, S.-F. Sensors Actuators B: Chem. 2011, 152, 88-93 .

47. Qiu, S.; Gao, S.; Liu, Q.; Lin, Z.; Qiu, B.; Chen, G. Biosens. Bioelectron. 2011, 26, 4326-4330

48. Kear, G.; Barker, B.; Stokes, K.; Walsh, F. Electrochim. Acta. 2007, 52, 2343-2351.

49. Cattarin, S.; Musiani, M. Electrochim. Acta. 2007, 52, 2796-2805.

50. Jung, M.-H.; Lee, H. Langmuir. 2008, 24, 9825-9831.

51. Lee, C. Mater. Chem. Phys. 2009, 114, 125133. 